\title{
Polemik Produk Legislasi Dewan Perwakilan Rakyat (DPR) di Indonesia dari Tahun 2015-2017
}

\section{${ }^{1}$ Prawira Yudha Pratama}

\section{${ }^{2}$ Mia Sarmiasih}

${ }^{1}$ Ilmu Pemerintahan, Fakultas Ilmu Sosial dan Politik, Universitas

Mulawarman

${ }^{2}$ Departemen Politik dan Pemerintahan, Fakultas Ilmu Sosial dan Politik, Universitas Gadjah Mada.

Email:

1prawirayudha96@gmail.com; 2miasarmiasih96@gmail.com

\section{Artikel Info:}

Diterima : 01 November 2019

Direvisi : 10 November 2019

Dietujui : 30 Desember 2019

\begin{abstract}
ABSTRAK
Salah satu implikasi dari adanya perubahan politik pasca Reformasi 1998 telah mendorong lembaga DPR menjadi lebih demokratis dan akuntabel. Hal tersebut setidaknya memberikan performance baru bagi DPR yang sebelumnya dinilai kurang berperan dalam menjalankan fungsinya pada masa Orde Baru, maka pasca reformasi peran dan fungsi DPR RI dikembalikan ke koridornya sebagai lembaga legislatif yang menjalankan fungsi legislasi. Namun, didalam pelaksanaannya terjadi beberapa permasalahan. Pasca pemilu tahun 2014, tepatnya ditahun 2015 sampai 2017 ada beberapa RUU (Rancangan Undang-undang) yang tidak bisa diselesesaikan dengan baik oleh badan legislatife ini. Tercatat pada tahun 2015 dari 39 RUU prioritas hanya 3 yang akan disahkan. Setelah itu tahun 2016 dari 50 RUU prioritas hanya 10 Yang akan disahkan dan ditahun 2017 daru 52 RUU perioritas hanya 6 yang akan disahkan, ini jelas bahwa produk legislasi yang diahasilakn sanglah minim. Ini disebabkan oleh ketidakadanya komitmen badan legislatife didalam penyelesaian RUU. Tarik ulur kepentingan diinternal serta kepentingan individu maupun kelompok juga salah satu penyelesaian dan pengesahan RUU menjadi tertunda sehingga tidakadanya keharmonisasian didalam Badan Legislatif.
\end{abstract}

Kata kunci: Polemik, legislative,Dewan Perwakilan Rakyat (DPR).

\begin{abstract}
One of the implications of the political changes after the 1998 Reformation has pushed the House of Representatives to become more democratic and accountable. This at least provides a new performance for the DPR which previously was considered to have less role in carrying out its functions during the New Order, then after the reformation, the role and function of the DPR RI was returned to its corridor as a legislative body that carried out the legislative function. However, in its implementation, several problems occurred. After the 2014 elections, to be exact from 2015 to 2017 there were several bills (Draft Laws) that could not be properly resolved by this legislative body. In 2015, out of 39 priority bills, only 3 will be passed. After that in 2016, out of 50 priority bills, only 10 will be passed, and in 2017, from 52 priority bills, only 6 will be passed, it is clear that the resulting legislative products are minimal. This is caused by the lack of commitment of the legislative body in the completion of the bill. The tug of war of internal interests and the interests of individuals and groups is also one of the settlements and ratification of the bill being delayed so there is no harmony in the Legislature.
\end{abstract}

Keywords: Polemic, legislative, House of Representatives (DPR). 


\section{PENDAHULUAN}

Salah satu implikasi dari adanya perubahan politik pasca Reformasi 1998 telah mendorong lembaga DPR menjadi lebih demokratis dan akuntabel. Hal tersebut setidaknya memberikan performance baru bagi DPR yang sebelumnya dinilai kurang berperan dalam menjalankan fungsinya pada masa Orde Baru, maka pasca reformasi peran dan fungsi DPR RI dikembalikan ke koridornya sebagai lembaga legislatif yang menjalankan fungsi legislasi (membuat Undangundang), selain juga menjalankan fungsi budgeting (anggaran) bersama-sama dengan presiden, serta fungsi pengawasan atas pelaksanaan UU dan anggaran dalam penyelenggaraan pemerintahan yang dilakukan oleh eksekutif. Dalam menjalankan fungsinya, DPR periode 2014-2019 dinilai sangat rendah kinerjanya terutama dalam menjalankan fungsi legislasi. Fungsi legislasi dilaksanakan sebagai perwujudan DPR selaku pemegang kekuasaan membentuk undangundang. Fungsi ini paling dominan dan berpengaruh, karena melalui fungsi ini maka DPR dapat mempengaruhi semua aspek yang ada di Negara Indonesia. Namun fungsi ini ternyata berjalan tidak maksimal. DPR dinilai kurang produktif karena sedikitnya RUU yang berasal dari inisiatif dewan. Padahal sebagai wakil rakyat DPR dituntut untuk memaksimalkan fungsi ini untuk mensejahterakan rakyat Indonesia sesuai dengan salah satu kewajiban anggota DPR.

Penilaian kinerja legislasi ini tidak hanya dilihat dari sisi kuantitas produk yang dibuat namun kualitasnya juga menjadi faktor penting dalam menilai produk legislasi. Akan tetapi, alasan untuk mengejar kualitas dengan mengabaikan kuantitas juga bisa menjadi persoalan pada saat pencapaiannya sangat minim dibandingkan dengan perencanaan yang telah disusun. Pada tahun 2015 DPR hanya berhasil menyusun 2 Undang-undang dari 37 yang direncanakan (26 RUU usulan DPR, 10 RUU usulan pemerintah dan 1 RUU usulan DPD) Dua Undang-undang itupun masih berupa revisi, yaitu UU tentang Pilkada dan UU tentang Pemerintahan Daerah. Minimnya produk legislasi tersebut ditengarai oleh situasi politik yang lebih didiminasi oleh perebutan kekuasaan di DPR, mulai dari pertarungan merebut kursi pimpinan maupun alat kelengkapan DPR. Proses tersebut berimbas pada terhambatnya pelaksnaan fungsi-fungsi DPR, terutama fungsi legislasi. Penilaian kinerja legislasi DPR juga dikemukakan oleh Ketua DPR Ade Komarudin (periode 2016- 2019), dimana pada semester pertama tahun 2016 DPR sudah menyelesaikan 7 Undang-undang dan 4 perjanjian, masih ada 34 Undang-undang yang belum terselesaikan dan harus diselesaikan dalam pada semester ini. (Tempo.co.jakarta, Rabu 13 Juli 2016, jam 17.03).

Kondisi dan situasi tersebut dalam beberapa kasus, dilihat sebagai salah satu konsekuensi demokratisasi yang dijalankan di lembaga legislatif, dimana proses formulasi sejumlah undangundang menjadi berlangsung lama karena diwarnai perdebatan sengit (yang berlangsung di fraksi, komisi maupun badan legislasi DPR), bahkan ada yang deadlock, menjadi sangat menyita waktu, energi dan biaya, sehingga jadwal penyelesaian undang-undang tersebut meleset dari tengat waktu yang direncanakan. Namun di sisi lain, kurangnya produk Undang-undang yang dihasilkan DPR ditengarai karena tidak optimalnya DPR dalam menjalankan fungsi legislasinya, bahkan anggaran untuk pelaksanaan fungsi legislasi ini juga disinyalir membengkak karena banyaknya kegiatan kunjungan kerja dan studi banding DPR dalam rangkaian proses legislasi tersebut. Selain itu, terkait juga dengan ketentuan kewenangan badan legslasi DPR RI menurut ketentuan Undangundang No. 17 Tahun 2014 yang tidak memungkinkan adanya pengajuan Rancangan Undangundang inisiatif DPR RI oleh Badan Legislasi DPR. Pengurangan kewenangan tersebut membawa dampak dan pengaruh terhadap optimalisasi proses legislasi di DPR RI. Hal lain yang menyebabkan kurang berperannya DPR menjalankan fungsi legislasi dapat dilhat dalam aspek 
SDM, teknis administrastif maupun tarik menarik kepentingan (khususnya kepentingan politik) yang perlu dilakukan upaya untuk mengatasi permasalahan tersebut.

1. Bagaimana pelaksanaan Fungsi legislasi DPR (Dewan Perwakilan Rakyat) di Indonesia?

2. Mengapa terjadi banyak permasalahan yang membuat produktifitas lembaga legislative menjadi tidak maksimal sehingga kualitas dan kuantitas produk yang dihasilkan menjadi tidak baik (buruk)?

\section{METODE PENELITIAN}

Penelitian ini menggunakan metode kualitatif dengan pendekatan studi pustaka, melalui kajian literatur yang terkait dengan pelaksanaan fungsi legislasi DPR. Sumber data yang digunakan berupa sumber data yang berasal dari teks berupa buku, jurnal, media cetak, elektronik dan online yang berkaitan dengan permasalahan ini (Moleong,2012).

\section{TINJAUAN PUSTAKA DAN KERANGKA TEORI}

\section{Pengertian Perwakilan}

Menurut definisi Andrew Heywood (2014:346) pengertian perwakilan adalah sebagai berikut:

"Perwakilan adalah, secara umum, sebuah hubungan melalui mana seseorang atau sebuah kelompok membela atau bertindak untuk kepentingan sekumpulan masyarakat yang lebih luas."

Dari definisi di atas dapat disimpulkan bahwa seorang atau sekelompok wakil yang telah dipilih untuk memegang kewenangan harus bertindak menurut kepentingan yang diwakilkannya, baik yang bekenaan dengan kesepakatan sebelumnya yang telah dibuat antara keduanya saat kampenye maupun tindakan demi kebaikan yang terwakili.

Perwakilan diperlukan karena tidak mungkin seluruh rakyat yang banyak dan luas dapat berpartisipasi secara langsung dalam pemerintahan seperti dalam teori demokrasi langsung (klasik). Oleh sebab itu, partisipasi rakyat diubah kedalam bentuk tindakan memberikan suara setiap beberapa tahun sekali untuk memilih perwakilan-perwakilan mereka dalam pemerintahan (Demokrasi perwakilan). Perwakilan ini selanjutnya yang akan bertindak sesuai dengan kepentingan yang diwakilinya dalam proses pemerintahan.

\section{Lembaga Perwakilan}

Lembaga perwakilan, dalam pengertian yang sederhana dapat disebut sebagai badan yang berisikan para politisi yang menyatakan diri mewakili rakyat. Secara tradisional, lembaga perwakilan dihormati dengan status mereka sebagai wajah publik, bahkan demokrasi, dari pemerintahan. Lembaga perwakilan dikenal juga sebagai lembaga legislatif, majelis dan parlemen. Dalam kontitusi-konstitusi tertulis, mereka biasanya mendapatkan kedudukan yang terhormat, dengan disebutkan sebelum lembaga eksekutif dan lembaga yudikatif.

Lembaga Perwakilan menempati sebuah posisi penting dalam proses pemerintahan yang mempunyai fungsi perwakilan, legislasi, pengawasan, rekrutmen politik, dan legitimasi. Legislasi sering dipandang sebagai fungsi utama dari lembaga-lembaga perwakilan. Parlemen secara khas memiliki kekuasaan legislatif dengan maksud agar hukum yang dibuat akan dianggap otoritatif dan mengikat. Alasan ini berlaku karena dua hal, pertama, parlemen adalah sebuah forum yang di 
mana hukum-hukum yang diusulkan dapat secara terbuka dibahas dan diperdebatkan. Kedua, parlemen disusun sedemikian rupa sehingga memperlihatkan bahwa rakyat membuat hukum mereka sendiri (Heywood, 2014:546-554)

Jimly Asshiddiqie (2006) dalam bukunya "pengantar ilmu hukum tata negara" membagi fungsi legislasi kedalam empat bentuk kegiatan, yaitu pertama, prakarsa pembuatan undang-undang (legislative initiation); kedua, pembahasan rancangan undang-undang (law making process); ketiga, persetujuan atas pengesahan undang-undang (law enactment); dan keempat, pemberian persetujuan pengikatan atau ratifikasi atas perjanjian atau persetujuan internasional dan dokumen-dokumen hukum yang mengikat lainnya (binding decision making on international law agreement and treaties other legal binding documents) (Isra, 2010:77-79)

\section{Faktor yang Mempengaruhi Lembaga Perwakilan}

Menurut John K. Johnson (2005:7-10) terdapat beberapa faktor yang mempengaruhi lembaga perwakilan dalam melaksanakan fungsinya. Faktor-faktor ini dilihat dari tingkat kekuatan dan independensi parlemen dalam pemerintahan. Tingkat kekuatan dan independensi parlemen ini akan menentukan tipe parlemen tersebut dalam pemerintahan. Apakah parlemen tersebut masuk kedalam klasifikasi sebagai parlemen stempel, arena parlemen, parlemen transformatif atau parlemen yang sedang berkembang (emerging legislatures). Faktor-faktor tersebut sebagai berikut:

\section{Sistem Politik dan Pemilu}

Derajat pemisahan atau penyatuan antara cabang legislatif dan eksekutif bisa jadi faktor utama dalam menentukan kekuatan dan independensi legislatif. Terutama, pemisahan yang lebih tegas antara kekuasaan eksekutif dan legislatif dalam sistem presidesial mendorong badan legislatif untuk memainkan peran yang lebih independen dalam menjalankan fungsi pembuatan undangundang dan fungsi pengawasan dibandingkan dalam sistem parlementer.

Sistem pemilu dengan anggota tunggal (distrik) dimana konstituen di wilayah tertentu secara langsung memilih seorang calon. Calon dengan suara terbanyak yang akan menang, kemungkinan akan lebih independen dan responsif terhadap konstituen dibanding anggota parlemen yang dipilih dalam sistem proposional. Terutama jika wilayah pemilihan cukup kecil dan sering diadakan pemilihan, anggota parlemen mungkin akan lebih berhutang dan responsif terhadap kontituen dibanding terhadap partai politik mereka.

\section{Kekuasaan Formal Parlemen}

Kekuasaan formal parlemen, biasanya ditetapkan dalam konstitusi dan peraturan tetap (atau aturan prosedur), adalah faktor lain yang menentukan independensi dan kekuasaan parlemen. Beberapa parlemen menikmati kekuasaan formal yang luas, membiarkan anggota dan komite untuk mengusulkan undang-undang (bahkan undang-undang dengan dampak keuangan yang signifikan), untuk secara dramatis merevisi perencanaan pendapatan dan pengeluaran pemerintah (eksekutif), dan menuntut eksekutif untuk memperoleh persetujuan legislatif dalam meminjam uang. 


\section{Kemauan dan Ruang Politik}

Memiliki kekuasaan formal tidak berarti bahwa legislatif akan menggunakannya. Pada kenyataannya, konstitusi dan aturan tetap (standing orders) umumnya memberikan parlemen kekuasaan yang lebih besar dari pada yang pernah mereka gunakan secara efektif. Dua faktor yang berdampak pada bagaimana parlemen menggunakan kekuasaannya yaitu kemauan politik dan ruang politik.

Kemauan politik adalah kekuatan dari keinginan pemimpin parlemen dan anggota berpengaruh untuk melaksanakan atau memperluas kekuasaan parlemen. Kekuasaan yang diperoleh dalam satu tempat umumnya hilang di tempat lain, dan karena alasan ini, upaya pemimpin parlemen untuk memperluas peran parlemen harus membayar biaya politik yang timbul oleh mereka yang takut kehilangan kekuasaan mereka.

Ruang politik mengacu pada keinginan dari orang lain dalam lingkungan politik untuk menyerahkan atau berbagi kekuasaan politik dengan parlemen. Sistem politik otoriter menjamin kecilnya ruang politik untuk parlemen, sementara yang lebih pluralistik, akan menciptakan sistem yang lebih kompetitif. Di parlemen dimana disiplin partai kuat, banyak penggunaan ruang politik yang tersedia, dan setiap upaya untuk memperluas ruang politik, sebagian besar ditentukan oleh disposisi partai politik.

\section{PEMBAHASAN DAN TEMUAN}

\section{Jejak Record proses legislasi}

Sepanjang 2017, DPR telah menghabiskan 5 masa sidang yakni MS III, IV, dan V TS 20162017 serta MS I dan MS II 2017-2018. Secara umum, rencana sekaligus target legislasi DPR disusun untuk jangka waktu satu tahun. Daftar rencana dan target tersebut biasanya disebut Daftar RUU Prioritas Prolegnas. Daftar RUU Prioritas Prolegnas tahunan tersebut biasanya diturunkan ke dalam target dan rencana tiap-tiap masa siding yang disampaikan oleh Pimpinan DPR pada Pidato Pembukaan Masa Sidang. Proses pembentukan RUU selalu diawali dengan tahap perencanaan, penyusunan Draf dan Naskah Akademik (NA), Harmonisasi di Baleg, Meminta Persetujuan Presiden, Pembahasan di Komisi dan Pansus, Pengambilan Keputusan di Paripurna DPR. Evaluasi ini akan mengikuti tahapan pembentukan RUU tersebut dengan melihat poin-poin kritis yang mempengaruhi kinerja legislasi secara keseluruhan.

\section{Tahapan Perencanaan}

Perencanaan legislasi DPR menurut UU No 12 tahun 2011 disebut Prolegnas. Pasal 17 menyebutkan bahwa Prolegnas merupakan skala prioritas program pembentukan Undang-Undang dalam rangka mewujudkan system hukum nasional. Dengan konsep tersebut, kita menganggap bahwa RUU-RUU yang ditetapkan DPR dalam Prolegnas merupakan RUU yang telah dipertimbangkan sebagai skala prioritas. Oleh karena merupakan skala prioritas, RUU-RUU yang masuk dalam daftar Prolegnas pada prinsipnya harus disahkan menjadi UU.

Prolegnas yang disusun untuk jangka waktu 5 tahun (1 periode) kemudian ditata berdasarkan skala prioritas tahunan. Untuk itulah DPR bersama pemerintah dan DPD menyusun Daftar Prolegnas Prioritas setiap tahun. Prolegnas 2015-2019 secara keseluruhan berjumlah 185 RUU. 185 RUU Prolegnas tersebut selanjutnya diturunkan dalam rencana prioritas tahunan. 
Pada tahun 2015, DPR telah menyepakati 39 RUU Prioritas, tahun 2016 dengan 50 RUU, dan tahun 2017 ini dengan 52 RUU Prioritas.

Perencanaan DPR ini dinilai tidak memenuhi prinsip kerja yang efektif karena berulang kali terjadi rencana atau target yang dipatok selama setahun pada akhirnya hanya menghasilkan beberapa UU saja. Mestinya dengan hasil yang minim pada tahun sebelumnya, Prolegnas Prioritas tak perlu dijejali dengan banyak target RUU. Nyatanya DPR dan Pemerintah selalu saja menetapkan target prioritas yang bombastis. Mereka gagal untuk memahami skala prioritas sehingga yang penting adalah banyaknya rencana, bukan soal bagaimana mewujudkan rencana secara konsisten. Kegagalan tersebut menjadikan Daftar RUU Prioritas lebih tepat untuk dianggap sebagai daftar mimpi-mimpi DPR dan Pemerintah serta DPD.

\section{Tahap Penyusunan Draf dan Naskah Akademik}

Penyusunan draf dan Naskah Akademik sesungguhnya menjadi bagian paling penting untuk memastikan kelancaran proses pembentukan RUU selanjutnya. Jika Draf dan NA dibuat asalasalan, maka proses selanjutnya akan banyak dihabiskan dengan perdebatan-perdebatan konsep dasar. Arah dan tujuan sebuah RUU yang dibahas juga sangat ditentukan oleh konsepsi yang tertuang melalui Naskah Akademik. Dan nampaknya bagian ini yang selama ini kurang mendapatkan perhatian. Baik terkait dengan batas waktu maupun keseriusan pembuatan draf dan NA.

Tugas penyusunan RUU merupakan tanggung jawab masing-masing lembaga pengusul. Dari 52 RUU Prioritas 2017, 17 RUU masih dalam tahap penyusunan ini hingga penghujung tahun 2017. Itu artinya dalam konteks pemenuhan target prioritas, jelas bisa dikatakan bahwa DPR dan Pemerintah sama-sama telah gagal memenuhi target. Bagaimana bisa mengharapkan kinerja legislasi bisa bertambah jika 17 RUU yang menjadi prioritas bahkan mungkin belum terjamah sama sekali?

Dan beban terbesar dari kegagalan memenuhi target ini ada pada DPR, karena 11 dari 17 RUU yang masih bertahan di tahap penyusunan merupakan RUU usulan DPR. Mereka yang mengabaikan usulan mereka sendiri. Dengan catatan ini sesungguhnya tak ada alasan bagi DPR untuk membawa-bawa pemerintah dalam pusaran pertanggungjawaban rendahnya kinerja legislasi. Dibandingkan dengan beban pemerintah, DPR-lah yang paling banyak memikul beban tanggung jawab tersebut.

\section{Tahap Harmonisasi}

Harmonisasi dilakukan di Badan Legislasi DPR. Tahap ini semacam penyempurnaan yang dilakukan Baleg terhadap RUU yang disusun oleh AKD (Komisi dan Pansus). Ada 8 RUU yang hingga akhir 2017 masih dalam tahap harmonisasi ini. Tugas harmonisasi Baleg menjadi sulit karena draf dan naskah akademik yang disusun AKD tidak cukup memadai. Selain itu beban Baleg memang menjadi berat karena mereka harus bertanggungjawab untuk menyempurnakan draf yang disusun oleh semua AKD di DPR. Proses pembentukan RUU kadang terhambat karena beban yang dipikul Baleg terlalu banyak pada waktu tertentu yang membuat sebagian RUU harus menunggu selesainya proses harmonisasi RUU lainnya. Ke depannya harus dipertimbangkan mekanisme harmonisasi di Baleg ini. Bagaimana peran AKD untuk mengurangi beban dengan menyusun draf dan NA RUU secara memadai. Apa yang selama ini dikerjakan oleh Baleg bisa dilakukan di Komisi atau Pansus yang melakukan penyusunan RUU tertentu. 


\section{Tahap Pembicaraan Tingkat I atau Pembahasan RUU}

Setelah mendapatkan persetujuan Presiden, RUU kemudian dibahas oleh Komisi/Pansus bersama dengan Pemerintah. Akselerasi pembahasan memang sangat ditentukan oleh ketersediaan waktu dari DPR dan Pemerintah. Walaupun sesungguhnya alasan itu tak seharusnya dijadikan hambatan proses pembahasan. Mestinya bisa dipikirkan untuk mencari jalan keluar agar proses pembahasan tak terhambat dengan kesibukan Menteri terkait dari Pemerintah. Pemerintah mesti menyiapkan pejabat khusus yang bisa mewakili menteri dalam proses pembahasan. Dari pihak DPR, terkait proses pembahasan RUU tentu sangat diharapkan kedisiplinan para anggota untuk menghadiri rapat. Seringkali terjadi anggota DPR malas-malasan untuk mengikuti rapat. Hal ini juga bisa menghambat proses pembahasan yang cepat. Dari 52 RUU Prioritas 2017, 20 RUU diantaranya masih tengah dalam proses pembahasan Tingkat I. Jumlah ini sebenarnya cukup banyak untuk dikerjakan secara parallel. Padahal Komisi di DPR jumlahnya hanya 11 komisi. Bisa jadi RUU lainnya dibahas oleh Pansus. Akan tetapi anggota Pansus juga semuanya merupakan anggota Komisi tertentu. Tumpang tindih jadwal pembahasan sangat mungkin membuat pembahasan RUU menjadi tidak efektif.

Tak mengherankan jika proses pembahasan RUU tertentu kerapkali harus diperpanjang. Walaupun Pasal 140 Tatib DPR sudah menetapkan batas waktu 3 kali MS untuk menyelesaikan 1 RUU. Akan tetapi di Tatib itu juga dibuka peluang untuk memperpanjang proses pembahasan jika disetujui Paripurna. Aturan mengenai perpanjangan waktu ini sesungguhnya berarti tak adanya batas waktu perpanjangan pembahasan.

DPR sungguh menikmati longgarnya peraturan yang mereka buat sendiri. Kesadaran mereka yang cenderung anti kedisplinan membuat mereka tak merasa punya keharusan untuk menepati batas waktu pembahasan selama 3 kali masa sidang. Karena hanya perlu mendapatkan persetujuan di Paripurna, mereka dengan mudah untuk terus mengulur-ulur waktu pembahasan. Penulis kira ini factor utama yang menghilangkan konsistensi DPR dalam proses pembentukan RUU. Peraturan yang longgar membuat DPR bisa seenaknya saja menyelesaikan pembahasan tanpa perlu dikerjar-kejar deadline. Hal ini juga yang dengan sistematis memelihara budaya DPR yang tidak konsisten, tidak disiplin, malas dan santai.

Pada rapat paripurna 7 Desember, DPR lagi-lagi dengan kompak menyetujui perpanjangan pembahasan 12 RUU. Ke-12 RUU tersebut adalah: RUU Pertembakauan, RUU Larangan Minuman Beralkohol, RUU Penerimaan Negara Bukan Pajak, RUU Ketentuan Umum Perpajakan, RUU Penyelenggraan Ibadah Haji dan Umrah, RUU Karantina Hewan, Ikan, dan Tumbuhan, RUU Pertanahan, dan RUU Perkoperasian, RUU Larangan Praktik Monopoli dan Persaingan Usaha Tidak Sehat, RUU Sistem Nasional IPTEK, RUU Wawasan Nusantara, dan RUU KUHP. Dari RUU-RUU ini ada yang perpanjangan waktu pembahasannya sudah lebih dari 10 kali masa sidang seperti RUU KUHP.

\section{Tahap Pengambilan Keputusan di Paripurna}

Ini merupakan tahap terakhir dari rangkaian pembentukan RUU di lingkup parlemen. RUU yang telah rampung di Pembicaraan Tingkat I lalu dimintakan persetujuan Paripurna untuk disahkan menjadi UU. Dari 52 RUU Prioritas 2017 hanya 6 diantaranya yang berhasil dibawa ke tingkat paripurna untuk disahkan menjadi UU. Minimnya RUU yang disahkan sangat tergantung pada proses pembahasan di Komisi dan Pansus 
Penilaian terhadap buruknya kinerja legislasi DPR selama ini banyak mengacu pada sedikitnya jumlah RUU yang diputuskan oleh Paripurna DPR selama setahun. Bayangkan saja, selama 3 tahun DPR 2014-2019 bekerja, mereka baru berhasil memparipurnakan 19 RUU Prioritas dengan rincian 3 RUU di Tahun 2015, 10 RUU tahun 2016, dan 6 RUU pada tahun 2017 ini. Tentu saja jumlah RUU yang dihasilkan tersebut sangat jauh dari target yang ditetapkan melalui Prolegnas Prioritas.
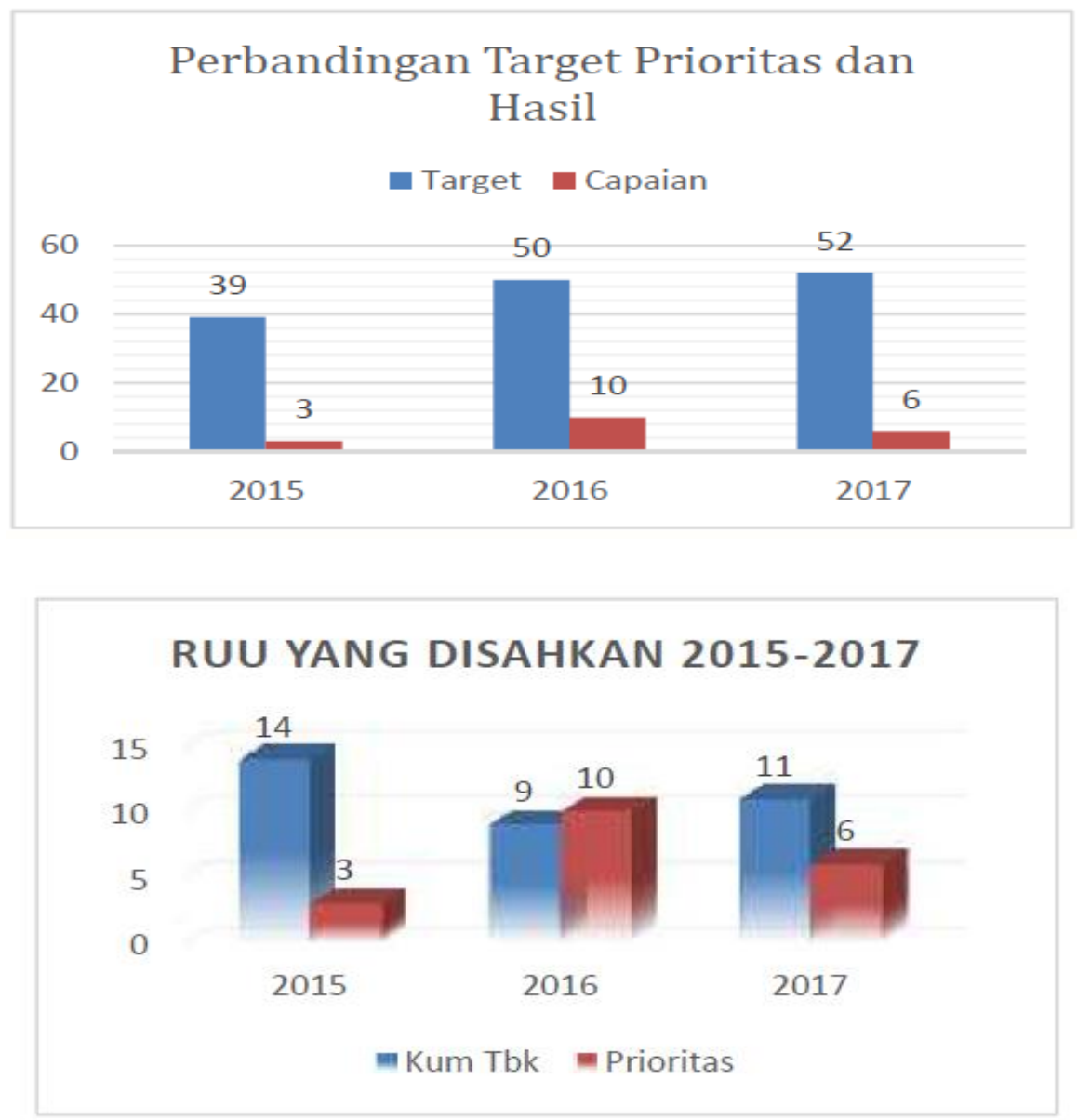

Beruntung saja ada jalur pengesahan RUU Kumulatif Terbuka yang jumlahnya selalu mampu menambal noktah kegagalan DPR dalam mengejar target RUU Prioritas. RUU Kumulatif Terbuka adalah kelompok RUU yang disetujui DPR karena akibat adanya ratifikasi perjanjian internasional, Pembuatan Perppu oleh Presiden, Pengesahan Anggaran dan Pertanggungjawabannya. Dengan atau tanpa perencanaan, DPR harus mengesahkan RUU-RUU tersebut. Tambahan dari pengesahan RUU Kumulatif serentak memperbesar angka RUU yang dihasilkan selama setahun. Tahun 2015 total UU yang dihasilkan berjumlah 17, di tahun 201619 RUU, dan tahun 2017 sebanyak 17 RUU. 


\section{Target}

Dari table target dan capaian berikut, nampak bahwa hanya dalam 3 MS DPR sungguhsungguh membuktikan kinerjanya secara signifikan yakni MS IV, V (2016-2017) dan MS I (20172018) dengan masing-masing menghasilkan 3,6, dan 7 RUU. Perencanaan legislasi setiap MS nampak sedikit membantu DPR untuk focus pada RUU tertentu yang ditargetkan.

\begin{tabular}{|c|c|c|}
\hline Masa Sidang & Target & Capaian \\
\hline $\begin{array}{l}\text { MS III TS } \\
\text { 2016-2017 } \\
\text { 10 Jan-24 Feb } \\
2017\end{array}$ & $\begin{array}{l}\text { 4 RUU } \\
\text { - RUU tentang Penyelenggaraan } \\
\text { Pemilu } \\
\text { - RUU tentang KUHP } \\
\text { - RUU tentang Pemberantasan } \\
\text { Tindak Pidana Terorisme } \\
\text { - RUU MD3 }\end{array}$ & $\begin{array}{l}\text { Tak Satu pun RUU yang } \\
\text { Disahkan }\end{array}$ \\
\hline $\begin{array}{l}\text { MS IV } 2016- \\
2017 \\
15 \quad \text { Mar-28 } \\
\text { April } 2017\end{array}$ & $\begin{array}{ll} & 10 \text { RUU } \\
\text { - } & \text { RUU tentang Penyelenggaraan } \\
& \text { Pemilu } \\
\text { - } & \text { RUU MD3 } \\
\text { - } & \text { RUU tentang KUHP } \\
\text { - } & \text { RUU tentang Pemberantasan } \\
& \text { Tindak Pidana Terorisme } \\
\text { - } & \text { RUU tentang Perlindungan } \\
\text { Pekerja Indonesia di Luar Negeri } \\
\text { - RUU tentang Penerimaan Negara } \\
\text { Bukan Pajak } \\
\text { - RUU tentang Arsitek } \\
\text { - RUU tentang Larangan Minuman } \\
\text { - } \text { Reralkohol } \\
\text { - RUU tentang Sistem Perbukuan } \\
\text { RUtang Kebudayaan }\end{array}$ & $\begin{array}{l}\text { 3RUU Disahkan } \\
\text { - RUU tentang Sistem } \\
\text { Perbukuan } \\
\text { - RUU tentang } \\
\text { Kebudayaan } \\
\text { - RUU pengesahan } \\
\text { Persetujuan Pemerintah } \\
\text { RI-Filipina tentang ZEE } \\
2014\end{array}$ \\
\hline
\end{tabular}




\begin{tabular}{|c|c|c|}
\hline $\begin{array}{l}\text { M5 Y } 2016- \\
2017 \\
18 \text { Mel-27 Jull } \\
20+7\end{array}$ & 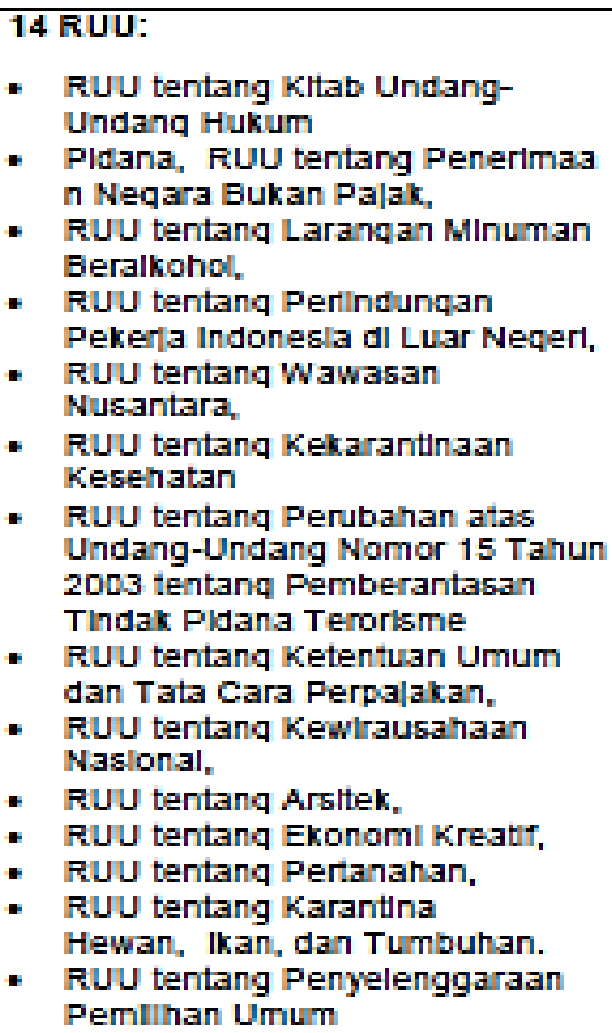 & 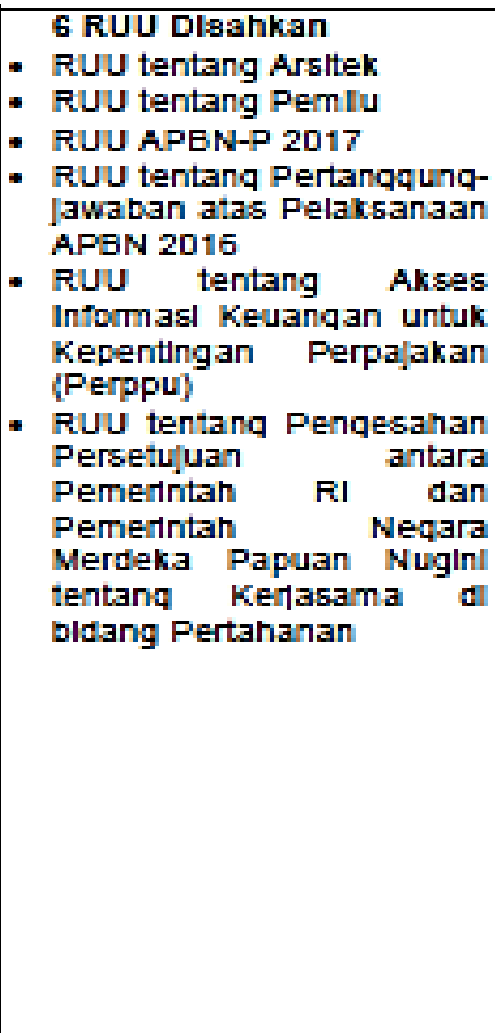 \\
\hline $\begin{array}{l}\text { M5 I } 2017- \\
2018 \\
16 \text { Agust-27 } \\
\text { Okt 2017 }\end{array}$ & Tlaak ada catatan & 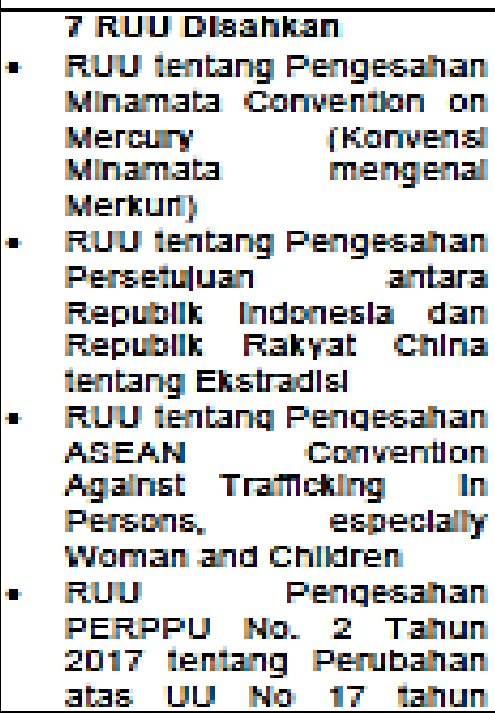 \\
\hline
\end{tabular}

Ada beberapa hal yang menyebabkan kurang maksimalnya pelaksanaan fungsi legislasi yang dijalankan oleh DPR 


\begin{tabular}{|c|c|c|}
\hline & & $\begin{array}{l}\text { 2013 tentang Organisasi } \\
\text { Kemasyarakatan } \\
\text { - RUU tentang Pengesahan } \\
\text { Protocol Amending the } \\
\text { Marrakesh Agreement } \\
\text { Establishing the World } \\
\text { Trade Organization } \\
\text { (Protokol Perubahan } \\
\text { Persetujuan Marrakesh } \\
\text { mengenai Pembentukan } \\
\text { Organisasi Perdagangan } \\
\text { Dunia) } \\
\text { RUU tentang APBN 2018 } \\
\text { RUU tentang } \\
\text { Perlindungan Pekeria } \\
\text { Migran Indonesia (PPMI) }\end{array}$ \\
\hline $\begin{array}{l}\text { MS II 2017- } \\
2018 \\
15 \text { Nov-13 Des } \\
2017\end{array}$ & Tidak ada catatan & - RUU Kepalangmerahan \\
\hline
\end{tabular}

Ada beberapa hal yang menyebabkan kurang maksimalnya pelaksanaan fungsi legislasi yang dijalankan oleh DPR antara lain juga berupa kendala dalam konteks mekanisme kerja DPR, yang menyebabkan banyaknya tugas yang telah dijadwalkan belum terlaksana secara maksimal, dimana banyaknya anggota DPR yang belum mematuhi apa yang menjadi kewajibannya. Dalam rapat pembahasan dan pengesahan Undang-undang jumlah anggota DPR harus hadir adalah $50 \%$, namun pada kenyataannya apabila yang hadir kurang dari $50 \%$ rapat paripurna walau dihadiri ketua dan wakil ketua DPRD tetap tidak bisa dilaksanakan karena menyalahi aturan suara dalam mengambil keputusan di DPR. Hal ini tentu berdampak terhadap waktu dalam pembahasan dan pengesahan yang diundur. Terkait dengan kondisi tersebut, dapatlah dilihat bahwa kurangnya kinerja DPR menghasilkan produk legislasi adalah karena aspek ketaatan anggota dewan dalam memenuhi jadwal legislasi. Hal tersebut berdampak pada tertundanya rapat pembahasan RUU karena tidak tercapainya kuorum dalam rapat. Demikian juga tentang Prolegnas sebagai instrument pembentukan Undang-undang yang belum ditaati oleh selu ruh anggota dewan. Hal lain yang menjadi penyebab kurangnya peran DPR dalam menjalankan fungsi legislasi adalah faktor sumber daya manusia yang meliputi kualitas anggota DPR dan pengalaman anggota DPR tersebut dalam menjalankan tugasnya sebagai anggota Dewan. Pemilu tahun 2014 merupakan pemilu yang berlangsung sangat terbuka dan demokratis dibanding dengan pemilu-pemilu sebelumnya. Sebagai dampak dari pemilu yang demokratis tadi, maka wakil yang duduk di DPR merupakan cerminan dari wakil-wakil yang representatif. Namun yang menjadi pertanyaannya, apakah representatif tersebut didukung oleh kemampuan sumber daya yang memadai. Artinya kemampuan anggota DPR dalam menjalankan fungsi legislasi dapat dilihat dari kualitas anggota DPR tersebut yang terpilih dalam pemilu legislatif tahun 2014. 
Kualitas anggota DPR tidak saja dilihat dari tingkat pendidikannya saja, namun juga dari segi kapabilitas dan integritasnya sebagai wakil rakyat. Peranan DPR dalam melaksanakan fungsi legislasi juga dipengaruhi sarana dan prasarana yang diperlukan guna menunjang berperannya DPR dalam menjalankan fungsi tersebut. Tidak seluruh anggota Dewan memiliki kemampuan secara teknis membuat draft naskah akademik sebagai salah satu aspek diajukannya rancangan Undang-undang. Apalagi bagi anggota DPR yang latar belakang pendidikan maupun pengalamannya belum pernah bersentuhan langsung dengan hal tersebut. Untuk itu diperlukan adanya fasilitas dan tenaga ahli DPR untuk membantu anggota DPR dalam menjalankan fungsi tersebut, guna menunjang kualitas sumber daya manusia anggota DPR. Secara umum tidaklah dipungkiri bahwa tingkat pendidikan anggota DPR periode ini relatif lebih baik dibandingkan dengan periode-periode sebelumnya. Namun tingkat pendidikan juga harus dibarengi dengan kualitas skill masing-masing individu anggota dewan, juga dalam penguasaan berbagai informasi dan keahlian dalam menjalankan fungsi legislasi maupun dalam melakukan komunikasi politik (lobby politik) sebagai rangkaian dalam proses legislasi. Dari segi SDM ini, faktor pengalamanlah yang banyak mempengaruhi kinerja setiap anggota DPR dalam menjalankan fungsinya. Minimnya pengalaman anggota DPR mengenai teknik perumusan RUU menyebabkan adanya kesulitan dalam pembahasan tersebut, terutama bagi anggota DPR yang baru duduk sebagai wakil rakyat dan belum memiliki pengalaman maupun belum pernah atau jarang melakukan aktivitas pelaksanaan fungsi legislasi sebelumnya. Pada prinsipnya, pengalaman anggota DPR secara signifikan berpengaruh terhadap pelaksanaan tugas-tugas yang diemban, karena pengalaman tersebut akan menjadi dasar pijakannya dalam menghadapi suatu masalah. Bagaimana seorang anggota DPR bersikap, bertindak dan melakukan kegiatan merupakan salah satu cara agar keprofesionalismeannya tercapai. Pengalaman anggota DPR yang pernah duduk dalam lembaga legislatif sebelumnya berpengaruh terhadap pelaksanaan tugas pokok dan fungsi yang diembannya saat ini sebagai wakil rakyat, paling tidak dia dapat mengetahui kekurangankekurangan yang ada pada periode sebelumnya untuk kemudian berusaha memperbaikinya dengan langkah-langkah yang lebih tepat. Pengalaman sebagai anggota DPR atau legislatif sangat diperlukan walau tidak ada pembelajaran sebelumnya mengenai legislatif.

Pengalaman anggota DPR dalam organisasi kemasyarakatan juga sangat penting dan sangat mendukung kemampuan anggota DPR dalam melaksanakan tugas legislasi. Anggota DPR yang sudah berpengalaman dan berkecimpung dalam organisasi kemasyarakatan akan menunjukkan kinerja dan hasil yang berbeda dengan anggota DPR yang baru duduk sebagai anggota DPR dan kurang berinteraksi atau tidak berkecimpung dengan organisasi kemasyarakatan. Seorang anggota Dewan yang sudah terbiasa menjalani kehidupan dengan banyak orang, sudah menjadi terbiasa menjalankan tugasnya sebagai wakil rakyat, dimana ia tidak akan merasa terbebani, namun kalau tidak terbiasa maka akan merasa dibebani dengan amanah ini. Pengalaman anggota DPR memang berpengaruh dalam menjalankan fungsinya sebagai wakil rakyat, tetapi bukan segala-galanya, karena anggota DPR yang memiliki tingkat intelektual yang tinggi apabila tidak bisa mengerti, memahami, dan tidak dipercaya masyarakat, tidak akan menolong meningkatkan produktivitas DPR itu sendiri. Oleh karena itu, untuk meningkatkan produktivitas DPR, masalahnya bukan semata-mata pada tingkat pendidikan formal para anggotanya maupun atas dasar pengalamannya, tetapi terutama pada tingkat pemahamannya kepada rakyat (terhadap aspirasinya, kebutuhannya, dan masalahnya), tingkat keberanian untuk memperjuangkannya secara proporsional serta memperoleh kepercayaan masyarakat. Faktor kerjasama antara anggota DPR lainnya juga 
berpengaruh dalam penyusunan suatu rancangan Undang-undang (kebijakan). Selain itu, kemampuan anggota DPR juga dipandang sebagai cerminan dari masyarakat, sehingga kualitas dewan dan anggotanya merupakan cerminan dan gambaran dari kualitas masyarakat secara keseluruhan. Dalam hal ini kerjasama yang dilakukan di antara anggota dewan, hendaknya tidak semata-mata atas dasar kepentingan kelompok (partai politik) tetapi lebih mengedepankan kepentingan masyarakat, yang telah memberikan mandat pada anggota dewan sebagai wakil rakyat dalam membuat dan menghasil kebijakan dengan tujuan untuk kesejahteraan rakyat. Selain disebabkan beberapa faktor tersebut, kurangnya produktivitas DPR menghasilkan kebijakan sebagai pelaksanaan fungsi legislasi ditengarai oleh adanya degradasi wewenang badan legislatif yang mengalami perubahan pasca revisi UU No. 27 Tahun 2009 tentang MPR, DPR, DPD dan DPRD menjadi UU No. 17 Tahun 2014, yang berimbas hilangnya salah satu kewenangan substansial Badan legislasi DPR, yaitu kewenangan untuk mengajukan usul inisiatif perubahan sdan Rancangan Undangundang (Tardjono, 2016: 12).

Dalam ketentuan UU No. 27 Tahun 2009, kedudukan Badan legislasi DPR RI adalah merupakan salah satu inisiator yang memiliki hak untuk mengajukan pembahasan Rancangan Undang-undang selain juga bisa dilakukan melalui usulan anggota DPR RI, Komisi dan gabungan komisi. Sementara dalam ketentuan yang baru yaitu dalam UU No. 17 Tahun 2014, usul rancangan Undang-undang hanya bisa dilakukan oleh anggota DPR RI, komisi dan gabungan komisi. Hilangnya kewenangan Badan Legislasi untuk mengajukan Rancangan Undang-undang inisiatif tentunya membawa dampak atau pengaruh terhadap pelaksanaan fungsi legislasi DPR RI. Implikasi tersebut nampak pada rendahnya pencapaian target legislasi pada tahun pertama DPR RI periode 2014- 2019. Dari 37 Rancangan Undangundang yang merupakan Rancangan Undangundang prioritas tahun 2015, hingga April 2015 baru 2 diselesaikan (Kompas, Prolegnas Bisa tidak tercapai, Kamis 16 April 2015, hal 2). Itupun pada penghujung tahun 2015 hanya bertambah 1 Rancangan Undang-undang, yaitu Rancangan Undang-undang tentang anggaran Pendapatan dan Belanja Negara yang memang mau tidak mau harus ditetapkan secara teratur setiap tahunnya. Keadaan tersebut bisa dibandingkan dengan pencapaian legislasi DPR RI periode 2009-2014 pada tahun pertama masa baktinya di tahun 2010 yang berhasil menyelesaikan 8 Rancangan UU menjadi Undang-undang. Hal ini menunjukkan degradasi atau perbedaan yang cukup jauh antara pencapaian legislasi DPR RI periode 2009-2014 dengan DPR RI periode 2014-2019. (Tardjono, 2016: 15). Salah satu permasalahan yang esensial dengan hal tersebut adalah karena hilangnya kewenangan Badan Legislasi dalam mengajukan Rancangan Undang-undang, yang menyebabkan kesempatan untuk menjadi inisiator dalam pembentukan Undang-undang semakin sedikit.

\section{KESIMPULAN}

Berdasarkan pembahsaan diatas dapat dikesimpulkan bahwa dalam Pelaksanaan fungsi legislasi terdapat degradasi kewewenangan badan legislatif yang mengalami perubahan pasca revisi UU No. 27 Tahun 2009 tentang MPR, DPR , DPD dan DPRD menjadi UU No. 17 Tahun 2014, yang berimbas hilangnya salah satu kewenangan substansial Badan legislasi DPR, yaitu kewenangan untuk mengajukan usul inisiatif perubahan dan Rancangan Undang-undang. Selain itu, temuan selanjutnya Dari segi perencanaan, Perencanaan DPR ini dinilai tidak memenuhi prinsip kerja yang efektif karena berulang kali terjadi rencana atau target yang dipatok selama setahun pada akhirnya hanya menghasilkan beberapa UU. DPR dan Pemerintah selalu saja menetapkan target prioritas yang bombastis. Mereka gagal untuk memahami skala prioritas 
sehingga yang penting adalah banyaknya rencana, bukan soal bagaimana mewujudkan rencana secara konsisten. Kegagalan tersebut menjadikan Daftar RUU Prioritas lebih tepat untuk dianggap sebagai daftar mimpi-mimpi DPR dan Pemerintah serta DPD. Tahap Tahap Penyusunan Draf dan Naskah Akademik, DPR dinilai tidak berkomitmen menyeleksi RUU yang telah dibuat. Seringsekali DPR menunda-nuda penyusunan dan pembuatan serta mengesahkan RUU. Dari segi harmonisasi, Proses pembentukan RUU kadang terhambat karena beban yang dipikul Baleg terlalu banyak pada waktu tertentu yang membuat sebagian RUU harus menunggu selesainya proses harmonisasi RUU lainnya. Ke depannya harus dipertimbangkan mekanisme harmonisasi di Baleg ini. Bagaimana peran AKD untuk mengurangi beban dengan menyusun draf dan NA RUU secara memadai. Apa yang selama ini dikerjakan oleh Baleg bisa dilakukan di Komisi atau Pansus yang melakukan penyusunan RUU tertentu. DPR sering terjadi konflik internal yaitu tarik ulur kepentingan didalam pengambilan keputusan sehingga ini salah satu pengesahan RUU jadi terhambat atau tertunda.

\section{DAFTAR PUSTAKA}

Apter, David E. 1985. Pengantar Analisa Politik, Jakarta : CV Rajawali. Assiddiqie

Heywood, Andrew, Politik edisi ke-4, Yogyakarta: Pustaka Pelajar, 2014.

Isra, Saldi, Pergeseran Fungsi Legislasi: Menguatnya Model Legislasi Parlementer dalam Sistem Presidensial Indonesia, Jakarta: Rajawali Pers, 2010.

Jimly. 2009. Pengantar Ilmu HukumTata Negara. Jakarta: PT Raja Grafindo Persada. Budiardjo, Miriam. 1989. DasarDasar Ilmu Politik, Jakarta : PT Gramedia.

Johnson, John K., The Role of Parliament in Government, Washington, D.C: World Bank Institute, 2005.

Lombo, Meigel Rio M. 2016. "Fungsi Dewan Perwakilan Rakyat dalam Penyelenggaraan Pemerintahan Setelah Amandemen UUD 1945". Dalam lex et Societatis, Vol. IV/No. /Feb/2016/Edisi Khusus. Marbun, B.N. 2002. DPR RI Pertumbuhan dan Cara Kerjanya, Edisi Revisi. Jakarta: PT Gramedia Pustaka Utama.

Pitkin, Hanna Fenichel. 2004. "Representation and Democracy: Uneasy Alliance". in Scandinavian Political Studies, Vol. 27 - No. 3, 2004.

Sanit, Arbi. 1982. Perwakilan Politik: Suatu Stdi Awal Dalam Pencarian Analisa Sistem Perwakilan politik di Indonesia, Imu dan Budaya, Edisi 2, tahun V. Jakarta : Universitas Nasional.

Tardjono, Heriyono. 2016. "Degradasi Kewenangan Legislasi Badan Legislasi DPR RI Pasca Revisi UU No 27 Tahun 2009 tentang MPR, DPR, DPD dan DPRD”. Jurnal Renaissance | Vol.1 No.01 | Mei 2016 | 11-16.

\section{WEBSITE}

http://www.tribunnews.com/nasional/2017/12/21/catatan-formappi-soalkinerja- dpr-dan-mkd-di$\underline{2017}$

http://www.bbc.com/indonesia/indonesia-42442235

http://www.beritasatu.com/nasional/469730-formappi-dpr-tidak-pernahbercermin- diri.html

https://www.cnnindonesia.com/nasional/20171221142208-32-264021/formappi-nilai- 2017-jaditahun-gelap-bagi-dpr

http://nasional.kompas.com/read/2017/12/21/14251331/jelang-tahunpolitik- dpr-diminta-buattarget-kinerja-lebih-realistis 